\title{
ASYLUM SEEKERS AND SECURITY AT THE NORTHERN FINNISH-RUSSIAN BORDER: ANALYSING THE "ARCTIC ROUTE EPISODE" OF 2015-2016
}

\author{
M. Piipponen, J. Virkkinen \\ Karelian Institute, University of Eastern Finland \\ 80101, str. Yliopistokatu 2, PL 111, Joensuu, Finland
}

\begin{abstract}
Europe experienced an unprecedented peak in asylum seekers in 2015. Over a million asylum seekers entered the European Union across the Mediterranean Sea and travelled by all means of transport, including by foot, from South to Central and Northern parts of the EU. This "migration crisis" became to define much of the political-territorial atmosphere in the continent with severe impacts on the European security but, significantly, also to the way countries communicated migration related threat images into desires for re-bordering.

Towards the end of 2015 and early 2016, a bit strange episode happened up in the North, when asylum seekers travelled to Northern Norway and Finland through Russian Federation. Despite locating very far from the Mediterranean and Balkan routes to Europe, the Russian North appeared to become part of so-called Arctic route to the Schengen area with over 7000 African, Middle-Eastern and Asian asylum seekers. Due to the history of very strict border management and control, very few illegal border crossings and extremely distant location, the "Arctic route episode" to Norway and Finland became matters of security in many ways.

After describing the overall character of this "Arctic route episode", we will analyse different perspectives to migration related security. A particular attention will be paid to Finland, Finnish border management and foreign citizens who applied for asylum at one of the "Eastern" border crossing points (Salla or Raja-Jooseppi) in Northern Finland. The Finnish-Russian case illustrates well the networked but still rather specific - migratory processes in Europe. The public discussion on the episode expresses well many of the international political fears and threats migration poses for those who actually are on the move.
\end{abstract}

Key words: Arctic route, asylum seekers, border management, European Union, Finland, Russia, security

\section{Introduction}

The contemporary literature on migration emphases that migration should not be studied just as a once-in-a lifetime relocation from point A to point B (e.g. Castles, Miller 2009). Migration is rather a complex process that can happen from different origins to different destinations through several steps and phases. Reasons and motivations for migration are not fixed but rather inconsistent and instable, and may change over time and space.

Europe experienced an unprecedented peak of asylum seekers in 2015. Over a million asylum seekers crossed the Mediterranean Sea and travelled by all means of transport, 
including on foot and by bicycles, from the South to Central and Northern parts of the European Union. This became to define much of the political-territorial developments in the continent with severe impacts on the Europe's security (see e.g. Virkkunen 2016) and, significantly, on the way the European Union, its member states and neighbours communicated the migration into desires for re-bordering.

Towards the end of 2015 and early 2016, a bit strange episode happened up in the North, when asylum seekers travelled to Northern Norway and Finland through the Russian Federation. Despite locating very far from the Mediterranean and Balkan routes to Northern Europe, the so-called Arctic route became one of the minor, but very much discussed, paths to the Schengen territory with approximately 7200 African, MiddleEastern and Asian asylum seekers. Due to its distant location and the history of very strict border control, only a very few illegal border crossings had taken place earlier. Therefore, this episode was something new and, thus, became matters of security both in Norway and in Finland as well.

After presenting the overall character of the "Arctic route episode" and placing it to a wider European context, we will analyse different perspectives to migration related security. A particular attention will be paid to Finland and the Finnish Northern borders. The Finnish-Russian case illustrates well the networked, but still rather specific, migratory process in Europe. The public discussion on the "episode" expresses well not only many of the domestic and international political fears, but also threats that migration poses for those who are on the move.

The paper is based on academic and media reports, seminar discussions and information received from publications (news, statistics, etc.) of and meetings with the Finnish Border Guard and the Finnish Immigration Service. In order to gain a better picture of what actually happened during the "Arctic route episode" and what impact it had for Finnish borders and security, these will be analysed by using qualitative content analysis approach.

Migration Routes to Europe: Majority of the over one million asylum seekers to Europe in 2015 came through so-called Mediterranean route from Turkey and North African Egypt and Libya to Greece, Italy and Bulgaria. With the better management of Greek, Turkish and Bulgarian borders, and asylum agreement between Turkey and the European Union, the number of newcomers dropped significantly to under 400,000 in 2016 (see below). Simultaneously, the route moved from the Turkish-Greek maritime border to longer and more dangerous Central Mediterranean, causing the drastic increase in the number of migrant deaths. The International Office of Migration IOM estimates that over 5000 persons went missing or died in the Mediterranean area in 2016 [IOM 2017], which is 35 per cement more than a year before.

Table 1

Immigration to the European Union (IOM 2016; 2017)

\begin{tabular}{|l|c|c|c||l|c|c|c|}
\hline & 2015 & 2016 & change & & 2015 & 2016 & change \\
\hline Greece & $\mathbf{8 5 7 3 6 3}$ & 176906 & $-79 \%$ & Malta & 106 & - & - \\
\hline Italy & 153842 & $\mathbf{1 8 1 4 3 6}$ & $+18 \%$ & Cyprus & 269 & 189 & $-30 \%$ \\
\hline Bulgaria & 31174 & 15962 & $-49 \%$ & TOTAL & 1046599 & $\mathbf{3 8 7} 739$ & $-63 \%$ \\
\hline Spain & 3845 & $\mathbf{1 3 2 4 6}$ & $+244 \%$ & Died/Missing & 3770 & $\mathbf{5 0 8 2}$ & $+35 \%$ \\
\hline
\end{tabular}


Within this context, the international border control and surveillance operations of the European Border Guard Agency FRONTEX turned to rescue operations where surveillance aircrafts and patrol boats detects overcrowded boats and rescue hundreds of migrants on a daily basis. Based on the above figures and stories by migrants, this so-called Mediterranean route is considered not only expensive but also extremely dangerous for migrants. In 2015, majority of the new arrivals to Greece were from the conflicted Syria (50.2\%), Afghanistan (20.2\%) and Iraq (7.1\%). In 2016, the central Mediterranean route to Italy was much more diverse: Nigerians (20.7\%), Eritreans (11.4\%) and a whole range of other nationalities. (IOM 2016; 2017).

Arctic route from Russia to Norway and Finland: The so-called Arctic route refers to a route that migrants (or later asylum seekers) took to Norway and Finland through the Russian Federation. On one hand, this was an alternative route to the so-called Mediterranean and Balkan routes that turned most popular and, later, difficult due to the re-bordering (and even fencing) of a number East and Central European states such as Serbia and Hungary along the route. On the other hand, approximately one fourth of the persons who entered Norway and Finland in the North, and asked for asylum, had a previous residence or a longer stay in Russia prior migration [Finnish Border Guard 2015b]. In other words, their migration through the "Arctic route" is only partly related to the broader migratory processes and, assumingly, to Russian restrictive asylum, immigration or labour policies that make third-country (not citizens of the Russian Federation or the Eurasian Economic Union) immigrants to relocate.

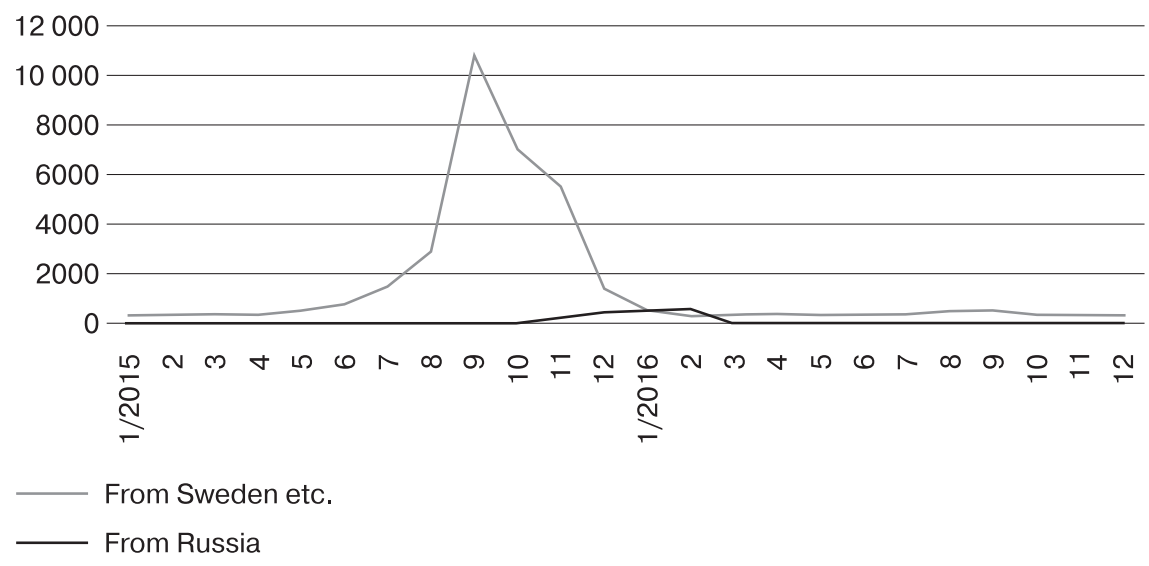

Fig. 1. Asylum seekers in Finland 2015-2016 by point of entry [Finnish Border Guard 2015-2016; Finnish Migration Service 2015; 2016]

The phenomenon of the Arctic route migration lasted mostly from October 2015 to February 2016. First, the migration of mainly Middle-Eastern, African and Asian citizens channelled through Moscow to Murmansk in the Russian North, and further to the Northern Finnmark province of Norway through a tiny border station called Storskog. During the 5 months, about 5500 asylum seekers entered Norway in Storskog to apply for asylum. Due to existing networks in Norway and Norway's reputation as a wealthy, tolerant and open society, Norway clearly was the destination country number one in the North. The neighbouring Finland was much less-known and became of interest only when Russian border guards began to require a valid Norwegian or Schengen visa from 
individuals at the Russian-Norwegian border. In other words, the pressure moved from Storskog to the Northern most border crossing points of Finland Raja-Jooseppi and Salla.

In Finland, the entire migration episode lasted less than a year, from May 2015 to January-February 2016. The peak of the phenomenon timed to August-November 2015 during which from a few up to ten thousand foreign citizens entered and applied for asylum in Finland each month. In total, 38,127 applied asylum in Finland during 20152016, out of which only 1756 (4.6\%) entered Finland from Russia [Finnish Migration Services 2015; 2016; Finnish Border Guard 2015-2016]. Compared to direct flight or maritime border crossings (by ferry from Estonia, Sweden or Germany), the SwedishFinnish twin city Haparanda-Tornio with no systematic border control appeared attractive and simple site for border crossing. Before introducing the intensified immigration monitoring in mid-September 2015 and opening the registration centre for asylum seekers a couple of weeks later, the lack of control and surveillance enabled the newcomers to relocate freely to other parts of the country.

During the period of 2015-2016, majority of the asylum seeker in Finland were Syrians $(21,732 ; 57 \%)$, Afghan $(5971 ; 16 \%)$ and Somali $(2413 ; 6 \%)$ [Finnish Migration Service 2015; 2016]. During the same period, citizens of up to 118 countries applied for an asylum in Finland [ibid.].

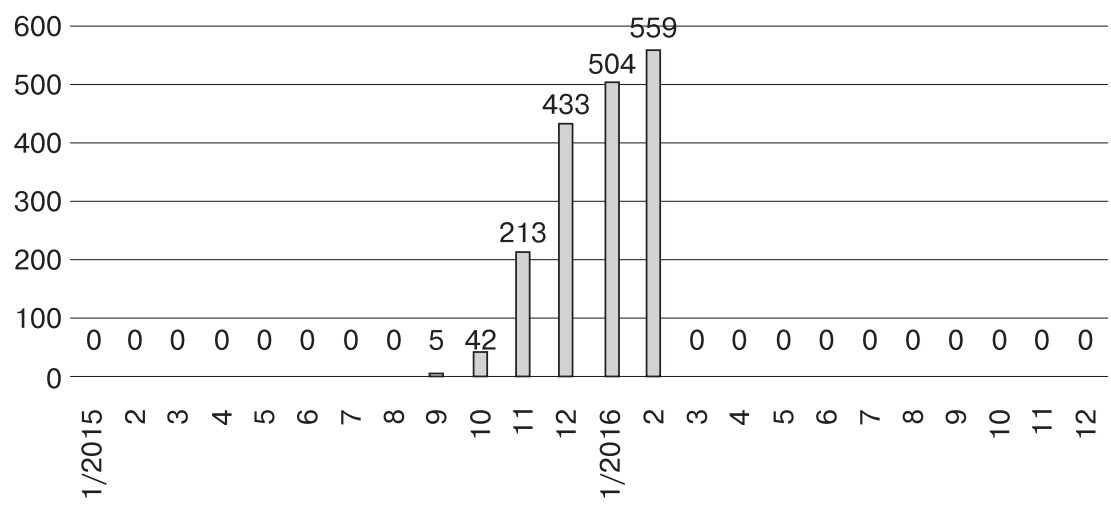

Fig. 2. Asylum seekers from Russia to Finland, 2015-2016, total [Finnish Border Guard 2015-2016]

The growth of asylum applications in late 2015 was evidently linked to Norway's and Russia's tightening border control at Storskog: when the traffic on the Norwegian border reduced, it moved to these two Finnish border stations. Even though the traffic started at the Norwegian border earlier, neither Finnish authorities nor non-governmental organisations were prepared to manage such a large quantity of applications. This led to a number of rapid, and even innovative, social, political and administrative solutions, e.g. distribution of snacks and tea for asylum seekers, regulation of incoming cars, that helped authorities and volunteers manage the situation as efficiently as possible.

In the following, we will look at two different aspects of the "Arctic route" at the Finnish-Russian border: Border management and security, and migrant security at and beyond borders. These illustrate the different levels of migration-security nexus and their concrete implications at the Finnish-Russian border. These also reveal some very concrete migration related insecurities in border management and among immigrants that will be studied in more detail in the latter part of this paper. 


\section{Asylum Seekers and Border Security at the Northern Finnish Borders}

Border Security in the North: As described above, the route to the Northern Finland was two-fold: so-called Balkan and Arctic routes. The former route reaches from the Mediterranean Sea and the Balkans to Central Europe, Denmark, Sweden and Finland, and the latter from the Middle East to Moscow and further to Murmask, Nikel and Kandalaksha in the North from where the migrants organized themselves (with or without assistance) to and across the border to Norway and Finland.

Like along the Balkan and Central and Eastern European routes, the 2015-2016 "migration crisis" discourse in the North was closely related to management and security: How to manage and get control over the border crossings that, to large extent, were illegal? Does that reflect wider political-territorial or human security concerns globally, or close to the Finnish borders? Despite the extremely cold climate during the winter months of arrival, and very peripheral location, the different borders in the North are different in terms of history, function and management. This was clearly manifested in the border related discourses and practices at particular borders.

In the West, the Finnish border to Sweden has been traditionally open for local border traffic. No passports or even ID's have been required from the citizens of the five Northern countries (Finland, Sweden, Norway, Denmark and Iceland) since 1950's. Since entering of Schengen area in 2001, the border can be crossed anywhere [Finnish Border Guard 2017; Niemenkari 2002]. All the five Northern countries, as well as most other EU and neighbouring states, are signatories of the Dublin agreement according to which the asylum applications of asylum seekers should be processed and decided in the first country of arrival. In the East, on the other hand, Finnish border to Russia has been relatively closed and very regulated since Soviet times. (see e.g. Laine 2015). Apart from very few special arrangements, the border can only be crossed at the official border crossing points and the border crossers need to carry both a passport and a valid Russian or Schengen visa.

Managing the "internal" borders of the EU: Majority of the asylum seekers during the 2015-2016 "immigration crisis" entered Finland through the "internal" EU border from Sweden with no systematic border control. Finland (and the Finnish Border Guard) did not introduce border checks at the "internal" (EU) borders - like Sweden, Norway and Denmark - but, instead, increased preparedness and capacity for immigration monitoring at the border area. That so-called "intensified immigration monitoring" (in Finnish: tehostettu ulkomaalaisvalvonta) opened space for deeper operational cooperation between Police, Finnish Border Guard and Customs in border areas and at international passenger harbours and airports such as Helsinki-Vantaa. The shipping companies were also obligated to comply carefully with their statutory manifests. [Intermin 2015].

As the "border control at internal borders does not prevent asylum seekers entering the country" [Intermin 2015], the aim of the "intensified immigration monitoring" was to gain information about the identity of people who entered and resided already in the country. The plan was to manage the immigration and registration of the asylum application better close to the border so that, as Deputy Department Chief Matti Sarasmaa from the Border and Coast Guard puts it, "this kind of free, reckless, peregrination [of asylum seekers] around Finland would not happen anymore" (Hiljanen 2015).

The Police Chief Seppo Kolehmainen and the Deputy Director of the Finnish Border Guard Matti Sarasmaa were rather optimistic with its impact: "The intensified immigration 
monitoring has the same result as restoration of border controls at the internal border" (Heikinmatti 2015). During 2015, the West Finland Coast Guard (that was responsible for the intensified immigration control in Tornio) patrolled over 2000 hours more than previous year, and conducted 7750 checks, which had an increase of $400 \%$ [Finnish Border Guard 2016].

Despite the optimism, the monitoring was rather labour intensive and required temporary transfer of staff members from other sections of the Finnish border, especially from Kainuu and Lapland Border Guard Districts, to the West. (Hiljanen 2015). At the same time, both non-governmental organisations and the official Non-Discrimination Ombudsman's office criticized the intensified immigration control of possible ethnic profiling. As Senior Adviser Robin Hams from the Non-Discrimination Ombudsman's office well puts it: "In today's Finland it is all too old-fashioned to make any conclusions based on skin colour. We have Finnish citizens with all skin colours. [...] No-one should have to experience that he or she is picked for check because of skin colour. If that takes place, it is a serious offence and misconduct" (Malminen 2016). Within this respect, the new operational model of the Police, Border Guard and Customs may have a serious impact on the immigrants' feeling of equality and security in Finland.

The "Eastern border" to Russia: The Finnish-Russian border, often referred to as 'the Eastern border' of Finland, was managed in a completely different manner than the Swedish. During the Soviet times, the most sections of the border were completely closed to all forms of traffic, including all forms of tourism and transport. As the forefront between the 'East' and the "West", the border and border areas were closely guarded and monitored both by Finnish and Soviet border guards, and the border could be crossed only in official border crossing points.

In order to ensure a secure well-functioning border, Finland has several bilateral agreements with the Russian Federation (formerly with the Soviet Union) relating e.g. to the order and border incidents from 23 June 1960 (revised in 1969, 1979, and 1998), crime prevention from 5 March 1993, and border crossing points from 11 March 1994. [Kononenko, Laine 2008; Laine 2015]. In addition, the Finnish Border Guard and the Border Service of the Federal Security Service of the Russian Federation compiled a joint protocol in 2006 in order to improve cooperation between the two sides of the border and, especially, to combat cross-border crime activity more effectively. Still today, the Finnish and Russian border guards have intensive cross-border cooperation at four levels: the heads of the countries' Border Guard organisations, a joint working group, the regional border delegates, and the local control authorities (Laine 2015).

Finnish-Russian cooperation in border control has always been functional by nature (Kononenko, Laine 2008; Niemenkari 2002), which became a one of the questions during the Arctic route migration. As Laine (2015) well puts it, "the cooperation framework is built on the investigation and resolution of border incidents, exchanging information (7/24), cooperation at BCPs, risk analysis and other operational cooperation in the area of border crossing crimes, joint operations and exercises, and exchanges of experts and practices".

Arctic route and "the East": Due to a long tradition of cooperation between Finnish and Russian border guards at the relatively well-functioning border, there was a clear expectation that the Russian border would not be used as a route for migration into Finland or to the European Union. The very few illegal border crossings that have taken place during the recent years have mainly been incidents caused by tourists' human errors 
in navigation close to the state border or, in some cases, intentional prank-like episodes where a few individuals wanted to have a border experience for fun. These, as well as the very few illegal border crossings where a foreign (and in many cases Russian) citizens have applied for asylum, have all been reviewed in cooperation with Russian authorities.

Within this overall context, the increasing number of asylum seekers at the Storskog border crossing point in Northern Norway gave some indications that some movement of third country nationals may be taking place close to the Finnish border as well. In media publicity (and shared by many authorities), the main threats were not related to illegal border crossings as such but, rather, to global politics and criminal networks, functioning of the Russian border control, and migrant agency:

- Geopolitics: Global politics, deteriorating East-West relations and hybrid warfare;

- Transnational criminal networks: Human smuggling and criminality in the Arctic route;

- Border management: Third-country nationals in Russian border zone, despite high level of trust, professionalism and good relations between Finnish and Russian border guards;

- Migrant agency: Migrants' own agency and effort to relocate to the North.

The above concerns related to the Arctic route were clearly formed in the global political setting, experiences related to the Southern borders of the EU, and certain historical threat images where many of the threats in Finland come from "the East". The Russian relations to the European Union and many of its member states have deteriorated after Russian involvement in Ukraine and Syria, and previously Georgia. Even if the relations between Finland and Russia were formally good, repeating air space violations and the militarisation of the Baltic Sea area, and tougher parlance in international relations, have led to a certain feeling of insecurity and lack of trust.

Related to the issue of trust, the Finnish media paid attention to the Russia's sudden unwillingness to control its borders. According to a very common (but unverified) theory, "Russian authorities are involved. Without the permission of the security services nothing happens at the border. Local border guards and other authorities do what they are told, they don't apply" (Leinonen 2016). Even the Minister of the Interior Petteri Orpo encapsulates his the prevalent impression in the Finnish press (Tolkki 2016): "I do believe [that Russia could stop the asylum seekers crossing the border if it wanted] because the border control has worked for long time and the border crossing points in the South are functioning well. If Russia has a will, it can be organized".

As popular as the above-described hybrid warfare interpretation of the "Arctic route episode" in Finland is, a number of scholars do provide alternative explanations for the phenomenon as well. Arild Moe and Lars Rowe [2016] discuss this in the Norwegian context and conclude that the Russian authorities did nothing different from previous years. Instead, groups of transiting migrants waiting nearby the state border were negative for the Russian security as well, and not very cost effective if the state really wanted to have an impact on Norway (or in this case Finland). They rather believe in the actorness of migrants, and interpret the "episode" with the lower price and relative security compared to the Southern route to Schengen (see below).

The interview with Commander Vesa Blonqvist from North Karelia Border Guard District in Newspaper Karjalainen (Huotari 2017) is contradictory. On one hand, he is 
very concerned about the decreasing resources and reorganization of the border management in North Karelia: "We have to strengthen the border control. Cuts in surveillance have to simply come to the end. [...] For years, we have made changes that people cannot really see. We have decreased [personnel] and relocated from the North to the South, from the green border to border checks. Now the situation has to be turned" [ibid.]. He is rather concerned about the global migratory processes and Russia's position as one of the transit countries for migrants: "The world has shrunken. It is useless to think that North Karelia was a safe haven any more, a place that would not face any movement taking place in Europe. If the political atmosphere changes, the taps can open fast" [ibid.].

On the other hand, he does trust the Russian Border Services across the border: "The Russians work well and with professional pride, and we have to respond to these situations on our side of the border. [...] As the spring progresses, I assume that the Russian Border Services will start notifying how they have prevented entries in their side" (Huotari 2017). This is a good example of pragmatic Finnish-Russian cooperation in border management. So was the Finnish-Russian state-level agreement signed by President Sauli Niinistö and Vladimir Putin that was set to close the two Northern border crossing points Raja-Jooseppi and Salla for other than Finnish, Russian and Belarusian citizens for the period of 180 days. Even though the flow of asylum seekers had already stopped when it took effect on 10 April 2016, it was to ensure that the border crossing points would not be used for "illegal" crossings in the future.

\section{Migrant (In)security at and Beyond Borders Along the Asylum Seekers' Routes}

Migrant (in)security and routes: Security is a starting point for asylum seekers' journeys. When elaborated in the changing contexts of a whole journey, we can actually recognise the multiple ways in which questions of (in)security appear in, travel with and influence from the country of origin to the country of destination, as well as the stops and detours on the way. In this section, we scrutinize migrant security and how it meets border security.

International migration - regular or irregular — is not a straight once-in-a-lifetime movement with clear beginning and end. Routes can include stops and detours, as well as changes in the original motivations of mobility on the way and in relation to the experiences of (in)security. The reported stories of the Arctic route clearly suggest that the episode was not only part of to the wider migration phenomenon in Europe but had its specificities too, as migrants with varying and changing motives joined the early movers from Syria and Middle East (Vinogradov 2016). The wider context and migratory infrastructure along the route opened opportunities for people already residing in the Russian Federation.

Experienced security, or lack of it, is one of the basic driving forces when people decide to leave their homes in order to find dignified life and secure living somewhere else. However, this common nominator can be experienced due to variety of reasons, such as political conflicts and war, political and ethnic persecutions, lack of human rights, natural disasters, poor socio-economic conditions, etc. The asylum seekers who crossed the Finnish-Russian border in the North during 2015-2016 represented 30 different nationalities, e.g. Afghans, Syrians, Indians, Bangladeshi, Nepalese and Iraqis, but also for example, Palestinians, Chinese, Ghanan, Cameroonian, Moroccan (Finnish Border 
Guard 2015-2016, Saavalainen 2016). In Norway, the situation was similar. There Syrians made up circa 10-20 per cent of the incomers in the end, and many other nationalities were included too, for example Afghans, Iranians, Iraqis, Pakistanis, Somalis, and Ethiopians (Hohman, Laruelle 2016).

In addition, those who already were staying in Russia joined the transit route to Norway and Finland. According to Hohman \& Laruelle [2016], many of those who crossed the Norwegian border were in fact already based in Russia. Some Syrians were working in the region of Krasnodar, in southern Russia. Others, such as Afghans, had Russian visas as foreign students or resident's permits. Some had requested refugee status in Russia and, after the applications were turned down, decided to try Norway. In the beginning of 2016, Russian media (Vinogradov 2016) reported from the town of Kandalaksha, almost $200 \mathrm{~km}$ from the Finnish-Russian border, of young people from Ghana and Gambia. A group of them told that the financial support they got for their studies in Moscow from a sponsor back in their home country had stopped. They needed to find a way to earn a living and decided to try Finland. A young man told that he had to leave home because of family problems. Many of his acquaintances had told that Finland receives immigrants well, so he decided to try to get there, and had been on the move two months before arriving to Kandalaksha.

Migrants do tend to face threats and uncertainties along their routes. Exposure to inhuman and dangerous conditions offered by the criminal networks of traffickers, as well as to a sporadic information from different sources during the trip and uncertain or over optimistic expectations towards the new life are among the most obvious ones. Migrants do many decisions along their routes, but they can mostly weigh only the least difficult or dangerous options within the limits of imperfect information, or disinformation.

Arctic route as a better and safer choice? The reasons for the appearance of the Arctic route is the most discussed topic in Finland, as well as in Norway. As described above, public discussions have concentrated a lot on international politics. However, migrant security and issues migrants faced along their routes have received less attention. One main suggestion concerning the reasons for this route is that it was considerably cheaper and took shorter time than the Mediterranean route.

According to Laruelle and Hohmann [2016], a trip from Middle East to Murmansk ranged from USD 2000 to 2500 including a tourist visa to Russia and a flight ticket to Murmansk via Moscow, whereas crossing Mediterranean via Greece could have costed USD 18,000. However, because asylum seekers' origins varied a lot, also prices they paid varied. An asylum seeker who entered Finland, for example, told about prices of EUR 5000-6000, and an Afghan family had paid USD 23,000 for their trip to the RussianFinnish border (Skön 2017). The first users of the route obviously also benefitted most from the short time the 'Arctic route' took - three days at its best (Vinogradov 2016). Then, as the number of comers crew, traffic at the border was controlled, as well as demand for allowed vehicles of border crossing (bicycles, cars) crew and availability decreased, the waiting times of the asylum seekers got longer in the nearest border towns before they could approach the border [ibid.].

City of Murmansk is located still further away from the Norwegian and Finnish border stations ( $210 \mathrm{~km}$ from Storskog border crossing point; $240 \mathrm{~km}$ from Raja-Jooseppi and $415 \mathrm{~km}$ from Salla). The situation activated local smuggler and business networks too. Transportation costs from Murmansk to the border could sum up to USD 1800 - a driver 
usually drove migrants close to the border - or a-week waiting in a local hotel in the nearest border town, Nikel, $40 \mathrm{~km}$ to the Norwegian border, to USD 500 (Laruelle, Hohman 2016). And, as crossing on foot is prohibited in these border crossing points, the asylum seekers had to buy a vehicle in order to be able to cross the border in the end. According to Moe \& Rowe [2016: 87-91], crossing to Norway in Storskog happened mainly on used and new bicycles, which costed circa USD 200, and to Finland in RajaJooseppi and Salla on bicycles and worn-out used cars (that would be abandoned immediately after entering Finland) circa USD 200 per person. Finnish authorities banned bicycles in December, and the only possibility was to cross the border by a car after it [Finnish Border Guard 2015-2016].

If the presented figures are correct, the Arctic route obviously was preferred in some extent instead of the crowded Mediterranean route. In terms of migrant (in)security, the image presented by the media clearly shows how international trafficker networks were involved in organizing the trips, and migrants met also varying local smuggler and business networks who used the opportunities for profiting of the their precarious lives. From the perspective of migration-security nexus, this illustrates well the different levels and scales of security and shows, how the conditions and sources of (in)security and migrant's experiences of them change constantly along their journeys.

The migrants' experiences of security, and safety, was also one of the themes discussed in media reports and academic papers. On one hand, the Arctic route may have been cheaper and safer than the southern route in terms of trafficking. On the other hand, all the frost bites and, even, an incident of death (an Indian man freezing to death in a car) reveal well that the darkest and coldest winter months were something that the most of the immigrants were not aware of.

Nefissa Naguib [2016: 377] depicts a comparison of the different routes in the Norwegian context in the following quote: "A young Syrian woman is interviewed on the Norwegian evening news. Earlier this year other members of her family had fled to Germany. She stayed in Syria, waiting to hear from them before setting out herself. When she finally managed to get a call through to her family, they recounted the humiliating agonies they had endured on their journey through Turkey and advised her to find another route. She decided to take the new migration route to Europe, the safer and less expensive Arctic route, as far as possible from the horrors of war. She doesn't go into the details of her long journey, other than to say that she has been hungry for a couple of years, often dizzy from hunger. As she is interviewed in the polar night, she stands in front of a building decorated with Christmas lights, a Bethlehem star in each of the windows, skinny pines covered in frost in the background, snow on the ground: "I don't mind that my ears are frozen and that I can see my breath. I want to be safe and have a dignified life. Get a proper education, work, and be able to feed myself". The camera shows other Syrian families with young children, single men and women, and girls and boys, traveling alone".

The turn of the route to the Finnish border changed also the geographic conditions which the migrants needed to deal with. The closest town of Kandalaksha with accommodation capacity and other facilities is located almost $200 \mathrm{~km}$ away from the Finnish border. When, compared to the route to the Norwegian border from Nikel, the last section of the journey got longer as the weather conditions turned to the coldest during December-February. Migrants travelled even in $-30{ }^{\circ} \mathrm{C}$, by car, foot, bicycles or wrecked cars, in many cases without heating or winter tires, or any winter driving 
experience. Within this context, it was a miracle that only one person ended up dead because of cold.

Heli Saavalainen, a journalist of the leading newspaper in Finland Helsingin Sanomat, noted during her visit to Salla border crossing point in January 2016: "The incomers can be recognized quickly: Car with a Russian register plate stops at the border station, and nobody comes to the passport control. This is how also Bangladeshi men do. They step out from the car only when asked to do so. Rucksacks in their backs, they walk to the waiting room. Men tell that they spent six days in the car. They bought the car in Murmansk, and an unknown Russian driver drove them to Kandalaksha, almost $200 \mathrm{~km}$ away from the border. From there, men who were not used to the winter, drove to the border" (Saavalainen 2016).

The same article continues with the words of a Cameroonian man and his fellow travellers who got together in Murmansk in order to buy a car: "Both Russians and Finns gave food for free, men told. And police helped the men to get to the border by repairing the broken car" (Saavalainen 2016). Despite incidents of exploitation, some racism and prejudices, migrants faced certain kind of humanity and respect from the local population during their migration process as well.

Migrant (in)security and border security: Border crossing points are interesting sites for the examining migration-security nexus in more concrete. It is a concrete point where migrants' experiences of security meet border security that is directly linked to formal, strictly authorized and territorially defined security control. Border crossing is a critical place for noticing possible gaps between different forms and layers of security related to migration, and matters migrants have to deal with along their journeys.

As discussed above, the Arctic route episode was a surprise to Finnish authorities. Even after it finished, it is still not completely clear what actually changed and why the Russian Border Services did not perform as expected on the basis of the previous cooperation (Skön 2017). And, the situation was new to the small peripheral border crossing points that were mainly used to deal with local traffic and shopping tourists. Despite the limited resources, Finnish border authorities were persistent in following the statutory border control procedures (of both regular and asylum seeker traffic) and the registration of the asylum applications. The following quotes from the news of the Finnish Border Guard depict this well:

December $4^{\text {th }}$, 2015: "In order to maintain border security and fluent border traffic, Raja-Jooseppi border station is prepared to regulate the border crossing traffic so, that we are able to thoroughly take care of our duties with those resources that we have in our daily use. When necessary, the traffic is regulated, if big numbers of asylum seekers arrive from Russia. In order to regulate the border crossing traffic, it is temporarily stopped if necessary and opened again, when the statutory tasks are taken care of at the border station" [Finnish Border Guard 2015a].

December 28 ${ }^{\text {th }}$, 2015: “... Because cycling has become a modus operandi of illegal entry to the country at Raja-Jooseppi and Salla border stations, without any genuine intention to continue travelling by the bicycle after the border crossing, the Border Delegate of Lapland decided, that, starting on December 23 ${ }^{\text {rd }}$, 2015, border crossings are allowed only by cars in Salla and Raja-Jooseppi. In addition to be able to prevent illegal entry to the country, a reason for this is, that persons who are not used to cycling in winter conditions seriously endanger their own and other people's safety..." [Finnish Border Guard 2015b] 
Even though the emphasis was on formal duties and illegal immigration, the given reasons for tightened regulations consider partly migrant security as well. The border security was decisive for migrants' security (e.g. the waiting time behind and at the border), but all the applied actions of the Border Guard were not consistent. Safety of very inexperienced winter cyclists was considered as a reason for adapting the vehicle restriction, whereas restricting the number of cars at the border - and 10 cars only per day - did actually not add the safety of migrants. The winter conditions were harsh and it was a well-known fact that people were there, approaching the border and waiting.

However, the moment of border crossing and entering from Russia to Finland (and Norway) was obviously significant both for migrants psyche and for their status. After all the experienced uncertainties and threats of the journey, entering the border crossing point was not only exciting but also a big relief. In his documentary film, a Finnish journalist Patrik Skön [2017] interviewed a young man who had travelled all the way from Lebanon to the Finnish border. During the last part of his journey from Murmansk to the border, he experienced threatening and tense moments. Long drive from Murmansk started at night. The hotel owner organised him a sudden departure after two unknown men had harassed him at the hotel. However, the approaching group was not let through the Russian border then, and he needed to turn back and to pay 500 euros extra. Next day, the attempt succeeded and, after being left close to the border, he cycled the last kilometres to Finland: "When I arrived, there was a polite Finnish border guard receiving us. We told him that we apply for asylum. He took a photo of me, took fingerprints, and we were transported by bus to the reception centre of Rovaniemi" (Skön 2017).

Before applying for asylum, persons entering Finland without a valid Finnish or Schengen visa are being considered as criminals, and the incident is investigated as illegal border crossing. Based on the United Nations Geneva Convention, and its supplementary protocol, applying for asylum at the border writes however out the illegality of the entry and the investigation follows asylum procedure instead of a criminal investigation. From this perspective, the consistency and reliability of the border authorities in their tasks in this case asylum registration - enhanced migrants' security. And, for example in the premises of the Salla border station, volunteers of the Finnish Red Cross provided snacks, sandwiches and warm tea to the newcomers after the registration and while they waited for bus transportations to the recently opened registration centre in Tornio close to the Swedish border.

\section{Conclusions}

The paper looked at the "Arctic route episode" of the 2015-2016 migration to the Europe North and two major security related approaches to the "episode", i.e. border security and migrant security. Unlike the main route to the North through the Mediterranean and Balkan states, the Arctic route refers to migration through the Russian Federation. During the peak months of the event, over 5000 migrants entered Norway and 1700 Finland through the three Northernmost border crossing points to Norway and Finland (Storskog, Raja-Jooseppi and Salla) to apply for asylum. This phenomenon was part of the wider European migration process in which migrants from North-African and MiddleEastern countries entered the EU. However, the Arctic route had also specificities, for example about a quarter of all the applicants had resided in the Russian Federation already for months, or for years. 
From security perspective, the Arctic route example demonstrates well the multilayered character of borders and security. In a European "migration crisis" context, it became clear that the new forms of border and migration management schemes (including border checks, intensified immigration control, restrictions negotiated with the Russian Border Services) were all balanced to manage the situation at the particular "internal" and "external" borders of the European Union in particular ways. Even though only less than five per cent of the 38,000 asylum seekers who entered Finland during the period used the Arctic route, the "Eastern border" to the Russian Federation was clearly portrayed as the bigger threat than the "internal" border to Sweden.

Instead of intensified immigration monitoring, the Raja-Jooseppi and Salla border crossing points to Russia were closed for most third-country nationals (except Belarus) after the "episode" was taken to bilateral state (President) level negotiations. The bilateral approach and, also, the decision were clearly related to Finnish historical interpretations of "the East", contemporary geopolitical realities in Europe, and certain issues of trust even though the formal relations with Russia were good. For migrants and asylum seekers, the process of migration through the Arctic was, seemingly cheaper and safer than through the Mediterranean. The phenomenon was part of the wider European migration process in which migrants from North-African and Middle-Eastern countries entered the EU. However, the Arctic route had also specificities and generated connections to other migratory processes too. For example, about a quarter of all the asylum applicants had resided in the Russian Federation already for months, or for years.

Overall, the "Arctic route" depicts well how a single migration episode was narrowly politicized and securitized by nation states. Despite contradictory approaches to the topic in most receiver countries, the trend is to reduce immigration and security to the traditional national security that does not leave much space for elaborating the actual multilayered character of security, and the lack of security of those who are on the move (see Virkkunen 2016; Castles, Miller 2009: 211-214). This type of conceptualization blurs the connected and specific nature of global migration processes and, thus, the needs for joint international discourses on the root causes and consequences of, as well as solutions for migration issues. Here, migratory routes, and different forms of security along the routes, should be more in the focus as well. Finding solutions requires much more solid cooperation between domestic and international actors, as well as states affected, in international forums. Building borders and walls may seem effective in the short run but that actually solves nothing.

\section{REFERENCES}

Castles S., Miller M. 2009. The Age of Migration. International Population Movements in the Modern World. Fourth Edition. Palgrave Macmillan.

Finnish Border Guard 2015-2016. Rajavartiolaitoksen tiedotteet - News from the Border Guard. URL: http://www.raja.fi/tietoa/tiedotteet (accessed: 01.12.2016).

Finnish Border Guard 2015a. Raja-Joosepin rajanylitysliikenteessä mahdollisia katkoksia. Tiedote 4.12.2015. URL: http://www.raja.fi/tietoa/tiedotteet (accessed: 07.04.2016).

Finnish Border Guard 2015b. Sallan ja Raja-Joosepin rajanylityspaikoilla sallitaan vain autojen rajanylitykset. Tiedote 28.12.2015. URL: http://www.raja.fi/tietoa/tiedotteet (accessed: 07.04.2016). 
Finnish Border Guard 2016. Länsi-Suomen merivartiostolla vilkas vuosi 2015. Tiedote 27.1.2016. URL: http://www.raja.fi/tietoa/tiedotteet (accessed: 19.02.2017).

Finnish Border Guard 2017. Border Crossing. URL: http://www.raja.fi/guidelines/border_crossing (accessed: 08.11.2017).

Finnish Migration Service 2015. Statistics on asylum and refugees. URL: http://www.migri.fi/about_ us/statistics/statistics_on_asylum_and_refugees (accessed: 08.11.2017).

Finnish Migration Service 2016. Statistics on asylum and refugees. URL: http://www.migri.fi/about_ us/statistics/statistics_on_asylum_and_refugees (accessed: 05.11.2017).

Heikinmatti A. 2015. Poliisi ja Rajavartiolaitos: Tehostettu ulkomaalaisvalvonta tuo saman tuloksen kuin sisärajatarkastukset. Helsingin Sanomat, 18.9.2015. URL: http://yle.fi/uutiset/3-8315543 (accessed: 08.11.2017).

Hiljanen P. 2015. Tehostettu ulkomaalaisvalvonta käynnistetään - raja, poliisi ja tulli yhteistyöhön Torniossa. YLE 15.9.2015. URL: http://yle.fi/uutiset/3-8306444 (accessed: 20.10.2017).

Hohmann S., Laruelle M. 2016. From the Mediterranean to the Far North: A Refugees Corridor at the Russian-Norwegian Border. The Arctic Institute, Center for Circumpolar Security Studies. URL: http://www.thearcticinstitute.org/refugees-corridor-russian-norwegian-border/ (accessed: 05.06.2017).

Huotari V. 2017. Karsimisen tie on nyt käyty loppuun: Rajojen valvontaa on pakko vahvisata, jyrähtää Pohjois-Karjalan rajavartioston komentaja Vesa Blonqvist. Karjalainen, 27.3.2017.

Intermin 2015. Norjan rajatarkastuksia vastaavat toimet käytössä Suomessa jo syyskuusta lähtien. URL: http://intermin.fi/artikkeli/-/asset_publisher/norjan-rajatarkastuksia-vastaavat-toimet-kaytossasuomessa-jo-syyskuusta-lahtien (accessed: 20.12.2016).

IOM 2016. Mixed Migration Flows in the Mediterranean and Beyond: Compilation of Available Data and Information 2016. URL: http://doe.iom.int/docs/Flows\%20Compilation\%202015\%20 Overview.pdf (accessed: 20.12.2016).

IOM 2017. Mixed Migration Flows in the Mediterranean and Beyond: Compilation of Available Data and Information 2016. URL: http://migration.iom.int/docs/2016_Flows_to_Europe_Overview. pdf (accessed: 14.09.2016).

Kononenko V., Laine J. 2008. Assessment of the Finnish-Russian Border: The Case of Vaalimaa Border Crossing Point. The Finnish Institute of International Affairs Working Paper No. 57, Helsinki.

Laine J. 2015. Threats, Challenges, and Finnish-Russian Cross-Border Security Cooperation: a Finnish Perspective. - Eurolimes 20, P. 125-142.

Leinonen N. 2016. Näkökulma: Venäjä luo epävakautta Suomen rajalla. Iltalehti, 26.1.2016. URL: http://www.iltalehti.fi/pakolaiskriisi/2016012621021223_cm.shtml (accessed: 08.09.2016).

Malminen U. 2016. Poliisin tehostettu ulkomaalaisvalvonta joutuu selvitykseen - etnistä profilointia ei saisi tapahtua. YLE, 21.4.2016. URL: http://yle.fi/uutiset/3-8826698 (accessed: 20.02.2017).

Moe A., Rowe L. 2016. Asylstrømmen fra Russland til Norge I 2015: Bevisst russisk politik? Nordisk Østforum, 30 (2), 80-97.

Naguib N. 2016. Humanitarian Pluralism: The Arctic Passage in an Age of Refugees. - International Journal Middle East Studies 48(2), 377-381.

Niemenkari A. 2002. The Finnish Border Security Concept. Geneva Centre for the Democratic Control of Armed Forces (DCAF) Working Paper Series No. 7. Geneva. URL: https://www.ciaonet.org/ catalog/11813 (accessed: 20.04.2017).

Saavalainen H. 2016. Puolet turvapaikanhakijoista tulee itärajan yli Lappiin — "Maahantuloa pyörittää selvästi järjestäytynyt rikollisuus”. Helsingin Sanomat 16.1.2016. URL: http://www.hs.fi/kotimaa/ art-2000002880264.html (accessed: 03.09.2017). 
Skön P. 2017. Spotlight. Kun itäraja vuoti. Yle/Fem. URL: http://areena.yle.fi/1-3797243\#autoplay=true (accessed: 08.10.2016).

Tolkki K. 2016. Haluaako Venäjä näpäyttää Suomea päästämällä turvapaikanhakijoita Lappiin? YLE, 16.2.2016. URL: http://yle.fi/uutiset/3-8676927 (accessed: 20.04.2017).

Vinogradov I. 2016. Мигранты массово скупают в Заполярье машины, но многие ездят без прав. TACC. Информационное агентство России. URL: http://tass.ru/obschestvo/2649226 (accessed: 03.09.2016).

Virkkunen J. 2016. Borders, Extremisms, and the Feeling of Security: Uncovering the MigrationSecurity Nexus in Finland. In Riazantsev S., Pismennaya E. (edt.) New Directions of Demographic Policy of the Russian Federation in the Conditions of Economic Crisis. M.: Econ-Inform, Moscow. P. 292-301.

(C) Piipponen M., Virkkunen J, 2017

\title{
Acknowledgements:
}

The study was conducted with support of KONE Foundation and the Strategic Research Council of the Academy of Finland

Article history:

Received: 10 November 2017

Revised: 05 December 2017

Accepted: 30 December 2017

For citation:

Piipponen M., Virkkunen J. (2017) Asylum Seekers and Security at the Northern Finnish-Russian Border: Analysing "Arctic Route Episode" of 2015-2016. RUDN Journal of Economics, 25 (4), 518-533. DOI: 10.22363/2313-2329-2017-25-4-518-533

\section{Bio Note:}

Piipponen Minna, Dr. (Human Geography), Researcher, Karelian Institute, University of Eastern Finland.Contact information: e-mail: minna.piipponen@uef.fi

Virkkunen Joni, Dr. (Human Geography), Research Manager, Karelian Institute, University of Eastern Finland. Contact information: e-mail: joni.virkkunen@uef.fi

\section{БЕЖЕНЦЫ И НАЦИОНАЛЬНАЯ БЕЗОПАСНОСТЬ НА СЕВЕРНОЙ ЧАСТИ ФИНСКО-РОССИЙСКОЙ ГРАНИЦЫ: АНАЛИЗ «АРКТИЧЕСКОГО МАРШРУТА» В 2015-2016 гГ.}

\author{
Минна Пииппонен, Йони Вирккунен
}

\author{
Университет Восточной Финляндии, \\ ул. Улиопистокату 2, ПЛ 111, Йоэнсуу, Финляндия, 80101
}

Европа испытала беспрецедентный пик притока беженцев в 2015 году. Более миллиона просителей убежища поступили в Европейский Союз через Средиземное море, а затем, используя все виды транспорта, в том числе пешком, из Южной - в Центральную и Северную части ЕС. Этот «миграционный кризис» стал определять большую часть политико-территориальной атмосферы на континенте с серьезным воздействием на европейскую безопасность. 
Важно то, какую информацию транслировали страны о данных миграционных потоках. К концу 2015 года и в начале 2016 года появились беженцы, которые отправились в Северную Норвегию и Финляндию через Российскую Федерацию. Несмотря на то, что российский Север, находясь очень далеко от Средиземного и Балканского маршрутов в Европу, оказался частью так называемого арктического маршрута в Шенгенскую зону с более чем 7000 африканскими, ближневосточными и азиатскими беженцами. «Арктический маршрут» в Норвегию и Финляндию изучается с позиции безопасности, в силу достаточно строгого пограничного контроля.

Описав общий характер этого «арктического маршрута», авторы проанализировали различные перспективы безопасности, связанные с миграцией. Особое внимание уделено Финляндии, финскому пограничному управлению и иностранным гражданам, которые подали ходатайство о предоставлении убежища на одном из «восточных» пунктов пересечения границы в Северной Финляндии. Финско-российский эпизод хорошо иллюстрирует сетевые, но все же довольно специфические миграционные процессы, характерные для Европы в целом. Общественная дискуссия по этому эпизоду отражает многие международные политические опасения и угрозы, связанные с миграцией. Ключевые слова: арктический маршрут, беженцы, пограничное управление, Европейский союз, Финляндия, Россия, безопасность

Ключевые слова: арктический маршрут, беженцы, пограничное управление, Европейский союз, Финляндия, Россия, безопасность

\section{История статьи:}

Дата поступления в редакцию: 10 ноября 2017

Дата принятия к печати: 30 декабря 2018

\section{Для цитирования:}

Пииппонен М., Вирккунен Й. Беженцы и национальная безопасность на северной части финско-российской границы: анализ «арктического маршрута» в 2015-2016 гг. // Вестник Российского университета дружбы народов. Серия: Экономика. 2017. Т. 25. № 4. С. 518-533. DOI: 10.22363/2313-2329-2017-25-4-518-533

\section{Сведения об авторах:}

Минна Пииппонен, доктор географических наук, исследователь карельского института Университета Восточной Финляндии. Контактная информация: e-mail: minna.piipponen@ uef.fi

Йони Вирккунен, доктор географических наук, ведущий исследователь карельского института Университета Восточной Финляндии. Контактная информация: e-mail: Joni. virkkunen@uef.fi 